\title{
Social Media Used to Spread Vaccination Program: Case of Indonesia Vaccination Covid-19 Policy
}

\author{
Danang Kurniawan ${ }^{1}$, Arissy Jorgi Sutan ${ }^{2}$, Ilham Mufandi², \\ Eko Eddya Supriyanto ${ }^{4}$, Meida Rachmawati ${ }^{5}$ \\ Masters Government Affairs Adminsitration, Universitas Muhamamdiyah Yogyakarta ${ }^{1,2}$, \\ Indian Institute of Technology, Delhi ${ }^{3}$, STKIP NU Tegal ${ }^{4}$, Universitas Ngudi Waluyo \\ Semarang \\ \{kurniawand949@gmail.com ${ }^{1}$, arissyjorgisutan7@gmail.com²
}

\begin{abstract}
On 13 January 2021, the Indonesian government announces the Vaccination program in Indonesia; social media, especially Twitter, also tend about the Vaccination Program. This research aims to know what social media has been used about the Vaccination Policy in social media Twitter. This research uses a qualitative approach, which uses Q-DAS (Qualitative Data Analysis Sofware) to analyze it. The toll of analysis usingNvivo 12plus and using 9 Hashtags that relevant to the topic. This research found that: 1.) The topic of Vaccination Policy dominated with Vaccination narration with result $51,62 \%$. 2.) There also appears the relation of all those hashtags with quite a strong relationship; the highest point is 0,809096 . 3.) Popular word in this phenomena is using hashtags like \#vaksinasidimulai. The limitation of this research is only using hashtags data in the analysis. Recommendations another research that take the same theme can use digital data.
\end{abstract}

Keywords: Vaccination program; Covid-19; Social media

\section{Introduction}

In the year 2020, the Corona Virus Disaes or Covid-19 become pandemic and affect many countries in the world. The desires affect world health its also can increase mortality because of the Covid-19 [1]. To reduce the mortality from the Covid-19 its urgent to make the vaccine as soon as possible [2], [3]. At the beginning of 2021, Indonesia's government tries to start the vaccination program to reduce the pandemic effect. Using COVID-19 vaccines would significantly reduce current disparities and the overall disease burden due to COVID-19 [4]. The vaccination program in Indonesia has also become trending in Twitter trends Indonesia. In this case, we can see that netizens in the social media twitter also care about public issues like the Vaccination program in Indonesia.

\subsection{Social Media and Policy}

Social media has become extensive media, and it is cheap and easy to access. Besides, new media such as social media should also be discovered. I try to encourage a target group to shift 
of there ideologies; campaign messages should incorporate data and expert viewpoints [5]. Horowitz on Kaldy suggests there are some recommendations as a guideline the social media developing in political aspect like [6]:

a. The social media and political aspect should refer to the previous policy that related to social media.

b. Social media practice should use common sense and general guidelines in political aspects, especially in the policy sector.

c. Accountable for enabling selective posts where the facility is a topic of a subject matter.

Besides that, social media is the right platform to look at society's response about public policy: First, With large users show that social media can be the right place to rising voices about public policy in the region. Second, Social media gives society an option to access the information with ease and cheaper rather than other media to giving voice [7]-[9]. Social media can also see as a platform to collect social power like Twitter and Facebook, allowing the activist and online campaign and using social media as a platform of collective communication [10]-[12]. Every media has a unique side, Like the social media that can use everyone to interact, discuss and giving voice about some event, but the social media can provide the freedom of speech, but at the same time, some users cannot distinguish between freedom of speech and social ethics [13]-[16].

\subsection{Health Aspect and Policy}

Health policy is essential with the Covid-19 Pandemic situation. In this case, we need a policy that can afford that everyone has access to health. In this situation, policymakers should make the policy applied with high efficiency to reduce the Covid-19 Pandemic [17], [18]. For example, take a look at the china of vaccination program of Influenza. There are three points about health policy that should focus on three sectors: First, there should have a relation between management and policy related to the health sector. Second, society and the government should have an awareness of the health issue. Third, there must also appear intervention on accessibility and affordability [5], [19]. Like what Iran does to reduce this pandemic effect, some initiatives and regulations to vanquish the disease outbreak are being put in place as the virus rapidly reaches a deadlock. There is a need for rule induction, situational regulations, and efficient skills to mitigate this same infection in foreign nations is evident [20]. Another country also should help each other like the WHO (World Health Organization) told that the biggest takeaway from all of this is that while every other government can have its specific operating structure, regulation, as well as cultural identity, this same worldwide dissemination, including its COVID-19 pandemic has had no geographical boundaries. States to earmarked distinctions to exchange information and collaborate to handle an urgent worldwide epidemic are essential [21]-[25].

\subsection{Social Media and Rising Voice}

Social media become the media to shows the voice of society. In this case, social media is a platform to respond to the vaccination program that happened in Indonesia. Social media has changed the protest that happened with conventional to digitalize more using social media. Social media change society to be the brave rising voice by using social media as the platform. On the other's side, the netizen uses hashtags to make up the voice became the trend. Many movements and protests happen using social media as a toll, like what happened in the middle east during Arab spring [26]. Communication and interaction between many demonstrations 
activism throughout the Arab spring regions have recently become more robust. This also appears to have overridden its founded significant news outlets such as Tunisia, Egypt, Syria, and Yemen, when they should have been going through the instability. Authoritarian governments in both those nations had already forgotten flow with data and internet content detailing their corrupt activities, violations of human rights, as well as an end to civil liberties. Demonstrators within and without particular areas now use Facebook, Twitter, and YouTube as sites instead of free information circulation, which has been left entirely unscathed [26]. The most popular used in social media are using hashtags to share the content and rising voice to be trending social media Issues linked to equal political justice, and challenging infractions of voice in establishment media have arisen from the recent usage of hashtags such as \#BlackLivesMatter, \#GirlsLikeUs, and \#SayHerName [27], [28]. On the other side, the social media used, there some point that protestors could still benefit from using online platforms to increase their exposure. Even so, new media and aid corporations like to mute their critiques by giving them the ability to control with their exposure. The latter causes specular highlights in which company people take an unfair advantage because protestors exit alternate solution social networks [29]. Another challenge from the activist side, known as slacktivism and the instant public, is that instant activism can generate both the hot-issue public and slacktivists. The reason for slacktivism because once individuals accept a media platform hoax, those who are even less likely to participate throughout the debate in the first place. It involves appropriate visual behaviors, like connectivity, making comments, and likeability social media posts, even though explained throughout the "Discussion" segment [30].

This research aims to know what kind of social media is used in vaccination Covid-19 policy in Indonesia; the previous research talks about the vaccination policy without seeing the social media impact. This research tries to see the social media used in Indonesia's vaccination policy to reduce the Covid-19 Pandemic. In this case, there are define three questions there are:

Q1, What kind the social media topic or content that related to the vaccination program in Indonesia.

Q2, What kind of social media relation of those hashtags in the Vaccination program's social media talks in Indonesia.

Q3, What kind the narrative spread in social media about the vaccination issue in Indonesia.

\section{Methods}

This research uses a qualitative approach, which uses Qualitative Data Analysis Software (Q-DAS) to analyze social media data. The toll that using to analyze the data is Nvivo 12Plus. To deliver the value and result using descriptive way, it also used table and figure to make clear the reader about the analysis parts. This research also using social media data using nine hashtags in the Twitter trend that relevant to the vaccination of the Covid-19 Program. in this case the 9 Hahstags are: \#Vaksin, \#vaksinasidimuali, \#vaksinasimelawanpandemi, \#VkasinasiNasional, \#VaksinBiarTenang, \#VaksinCovid19, \#VaksinHalal, \#VaksinSinovac, \#vaksinuntukkita. The analysis parts using three analysis toll on Nvivo 12Plus: Chart analysis, Cluster analysis and Word Cloud analysis.

\section{Result and Disscusion}


This part tries to know what kind the social media phenomenon about the vaccination policy in Indonesia. These parts using three kinds of analysis, there is Chart analysis to know social media topic or content that related to the vaccination program in Indonesia, Cluster analysis to know social media relation of those hashtags in the social media talks of the Vaccination program in Indonesia, and word cloud analysis to know narrative spread in the social media about the vaccination issue in Indonesia. The analysis parts in down below.

\section{1 Social Media Content about Vaccination Policy}

This part tries to know what kind the content that spread on social media. using social media data specially using 9 hahstags there are: \#Vaksin, \#vaksinasidimuali, \#vaksinasimelawanpandemi, \#VkasinasiNasional, \#VaksinBiarTenang, \#VaksinCovid19, \#VaksinHalal, \#VaksinSinovac, \#vaksinuntukkita. in this parts uisng charts analysis which using 3 Nodes there are: Covid, Sinovac and Vaksinasi. The analysis parts in down below.

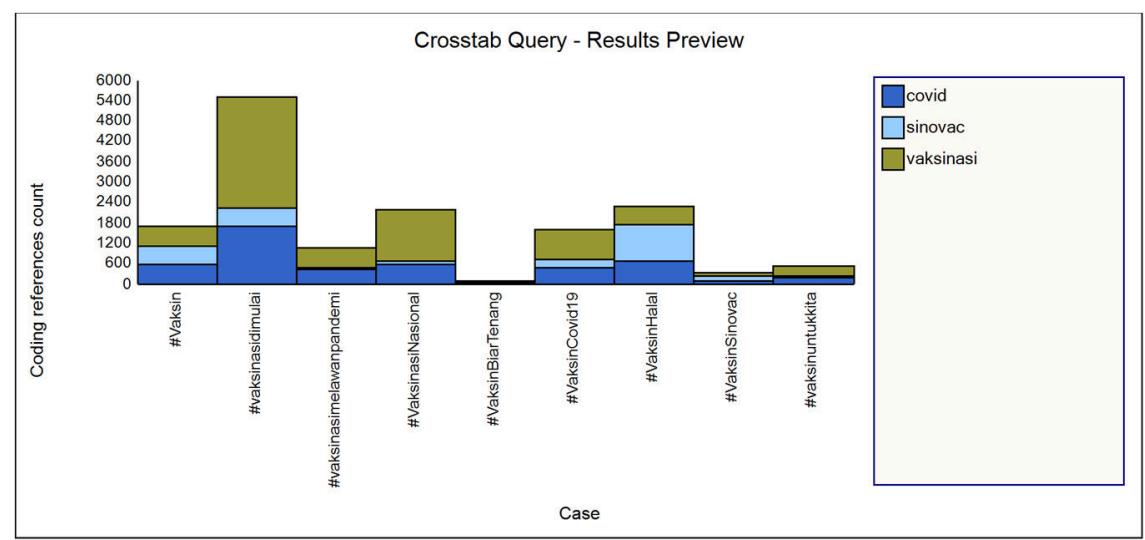

Fig. 1. Social Media Topic about Vaccination Program.

Table 1. Tablet Social Media Topic about Vaccination Program.

\begin{tabular}{ccccc}
\hline Hashtags & Covid & Sinovac & Vaksinasi & Total \\
\hline \#Vaksin & $33,29 \%$ & $31,79 \%$ & $34,91 \%$ & $100 \%$ \\
\#vaksinasidimulai & $30,45 \%$ & $10,08 \%$ & $59,47 \%$ & $100 \%$ \\
\#vaksinasimelawanpandemi & $38,99 \%$ & $2,94 \%$ & $58,06 \%$ & $100 \%$ \\
\#VaksinasiNasional & $27,2 \%$ & $4,23 \%$ & $68,57 \%$ & $100 \%$ \\
\#VaksinBiarTenang & $35,09 \%$ & $12,28 \%$ & $52,63 \%$ & $100 \%$ \\
\#VaksinCovid19 & $29,82 \%$ & $13,16 \%$ & $57,02 \%$ & $100 \%$ \\
\#VaksinHalal & $29,36 \%$ & $47,23 \%$ & $23,41 \%$ & $100 \%$ \\
\#VaksinSinovac & $31,39 \%$ & $33,66 \%$ & $34,95 \%$ & $100 \%$ \\
\#vaksinuntukkita & $29,28 \%$ & $15,78 \%$ & $54,94 \%$ & $100 \%$ \\
Total & $30,67 \%$ & $17,71 \%$ & $51,62 \%$ & $100 \%$ \\
\hline
\end{tabular}

In this case, we can see that social media content; in this case, there are three social media content nodes: Covid, Sinovac, and Vaksinasi. In nodes of Covid, the highest pole is \#vaksinasimelawanpandemi with $38,99 \%$, in the second pole is \#VaksinBiarTenang is $35,09 \%$, the third place is \#Vaksin is $33,29 \%$. Nodes of Sinovac, the highest pole, is \#VaksinHalal with 47,23\%. On the second pole is \#VaksinSinovac with 33,66\%. In third place is \#Vaksin with the result of $31,79 \%$. Nodes of Vaksinasi, the highest pole, is 
\#VaksinasiNasional with a result of $68,57 \%$. The second pole is \#VaksinasiNasional, with a result of $68,57 \%$. The third pole is \#vaksinasidimulai with $59,47 \%$. From the result's total result, the Highest result is the nodes of is Varanasi with 51,62\%. The second pole of the total result is nodes of Covid with $30,67 \%$. The third place is the nodes of Sinovac with $17,71 \%$. From this case, we can see the social media used to fly up the vaccination program's topic.

\subsection{Social Media Relation on the Vaccination Policy issue}

This analysis parts using Cluster analysis to know what kind the social media relation. The analysis using 0,5 lower limit and one upper limit. In this case, social media is used as the platform to know the relation of those hashtags in social media. This analysis using the scale from $-1,0$, and 1 as a reference in the upper limit and lower limit. the analysis following is down below.

Items clustered by word similarity

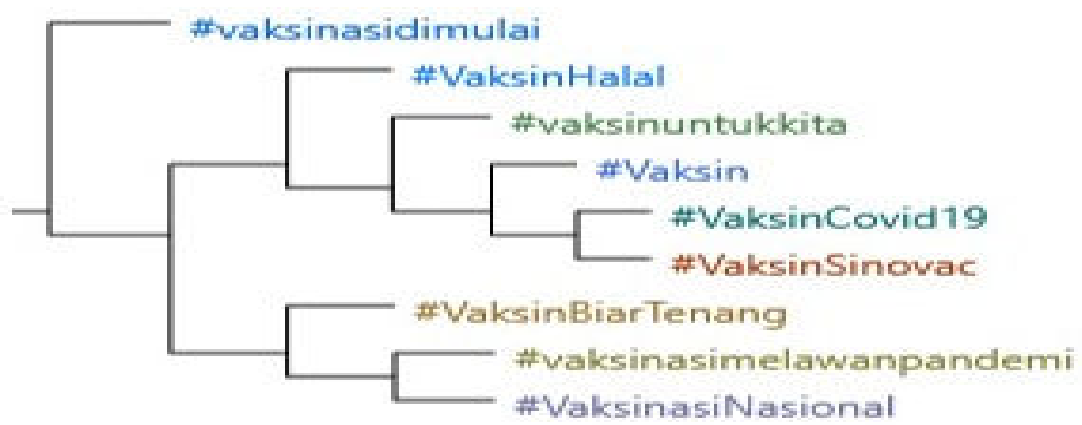

Fig. 2. Social Media Relation about Vaccination

Program. From the data, we can see that the relation of those hashtags we can see in 0,5 lower limit and the upper limit. the Highest relation is \#VaksinSinovac and \#VaksinCovid19 with 0,809096 score. The second pole of the relation is \#VaksinCovid19 with \#Vaksin, and the result is a 0,781341 score. The third place is relation \#vaksinuntukkita with \#VaksinCovid19, and the relation score is 0,756944. Fourth place is the relation of \#VaksinCovid19 and \#vaksinasimelawanpandemi, with the relation score is 0,750323 . The Fifth place is the relation between \#VaksinSinovac with \#Vaksin, and the relation score is 0,749446 . In this case, social media relation, we can see that the relationship appears and quite string because the relationship we can see in the 0,5 point lower limit and 1 point upper limit.

Table 2. Top 5 Relation Of Hashtags in Social Media About Vaccination Policy

\begin{tabular}{llc}
\hline \multicolumn{1}{c}{ Hashtags A } & \multicolumn{1}{c}{ Hahstags B } & Pearson correlation coefficient \\
\hline \#VaksinSinovac & \#VaksinCovid19 & 0,809096 \\
\#VaksinCovid19 & \#Vaksin & 0,781341 \\
\#vaksinuntukkita & \#VaksinCovid19 & 0,756944 \\
\#VaksinCovid19 & \#vaksinasimelawanpandemi & 0,750323 \\
\#VaksinSinovac & \#Vaksin & 0,749446 \\
\hline
\end{tabular}




\subsection{Narartive Speard in Soical Media}

Using a word cloud analysis with the word in the analysis figure is 100 famous words about Indonesia's vaccination policy. The analysis parts in below.

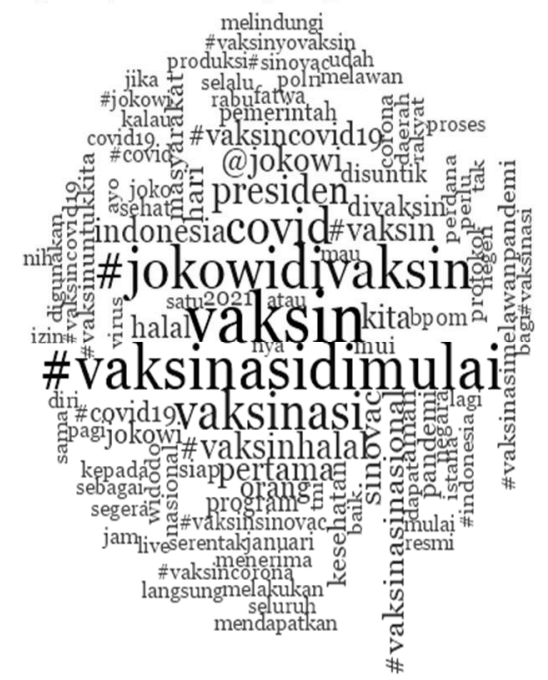

Fig. 3. Narration Spread in Social Media

Table 3. Top 10 Popular words in the Social Media about the Vaccination Program

\begin{tabular}{lr}
\hline Word & Count \\
\hline Vaksin & 18869 \\
\#vaksinasidimulai & 15992 \\
\#jokowidivaksin & 13939 \\
Vaksinasi & 11592 \\
Covid & 11203 \\
Presiden & 7187 \\
\#vaksinhalal & 6213 \\
Pertama & 5416 \\
@jokowi & 5410 \\
\#vaksin & 5197 \\
\hline
\end{tabular}

In this case, we can see single words dominate the narration that spread to support the Covid-19 vaccination program, such as Vaksin, Vaksinassi, Covid, and Pertama in the top ten the social media Twitter. The highest word is Vakasin, with a count is 18869 . On the other side, besides using single words, the hashtags in social media like \#vaksinasidimulai, \#jokowidivaksin, \#vaksinhalal, and \#vaksin. In this case, the narration spared a single domination word and the hashtags used to promote the vaccination program.

From the analysis parts, there are three various points, and there are 3 points that we can see there are:

a. The social media topics or content define in three dominant topics like Covid, Sinovac, and Vaksinasi, with the result are Highest result is the nodes of is Varanasi with 51,62\%. The second pole of the total result is nodes of Covid with $30,67 \%$. The third place is the nodes of Sinovac with $17,71 \%$. From this case, we can see that social media used to fly up a vaccination program's topic. 
b. Social media has a relation; in this case, social media relation is quite strong that we can see the relation with a lower limit is 0,5 , and the upper limit is 1 point. With the Highest relation is \#VaksinSinovac and \#VaksinCovid19 with 0,809096 score.

c. The social media narrative that spared dominated with the single words; besides that, the hashtags also appear in social media talk with the highest word is Vakasin with the count is 18869 .

From this point, we can see that tendency social media used to promoted the vaccination program. Using single words and hashtags and making the narration spread on social media can impact the netizen to participate in the vaccination program. The social media hashtags also show the relation that quite strong to look and indicated that those hashtags are connected with the same goals to promoted the vaccination program.

\section{Conclusion}

Social media, in this case, using to promote the vaccination policy in the case of Indonesia. It can see from three-point that: first, social media topics or content define in three dominant topics like Covid, Sinovac, and Vaksinasi. The result is Highest result is the nodes of is Varanasi with $51,62 \%$. The second pole of the total result is nodes of Covid with $30,67 \%$. The third place is the nodes of Sinovac with $17,71 \%$. From this case, we can see that social media used to fly up the vaccination program topic. Second, social media has a relation. In this case, social media relation is quite strong that we can see the relation with lower limit is 0,5 , and the upper limit is 1 point. With the Highest relation is \#VaksinSinovac and \#VaksinCovid19 with 0,809096 score. Third, social media narrative that is spared dominated with the single words, besides that, the hashtags also appear in social media talk with the highest word is Vakasin with the count is 18869 . The limitation of this research only focused on social media data to analyze this research. On the other side, the next research recommendation tried to use the digital data and focused on the pro-contra on social media in Vaccination policy.

\section{Acknowledgements}

Research journals related to vaccination policy communication express sincere appreciation to all reviewers for selflessly contributing their expertise and time to the review process, which is essential to ensure the journal's quality and substantive impact. Journal editors and co-authors acknowledge reviewers' efforts to evaluate and rate articles submitted for consideration.

\section{References}

[1] S. Schaffer Deroo, N. J. Pudalov, and L. Y. Fu, "Planning for a COVID-19 Vaccination Program," JAMA - J. Am. Med. Assoc., vol. 323, no. 24, pp. 2458-2459, 2020, doi: 10.1001/JAMA.2020.8711.

[2] S. M. C. Abo and S. R. Smith, "Is a COVID-19 vaccine likely to make things worse?" Vaccines, vol. 8, no. 4, pp. 1-13, 2020, doi: 10.3390/vaccines8040761.

[3] A. L. Phelan, "COVID-19 immunity passports and vaccination certificates: scientific, equitable, and legal challenges," Lancet, vol. 395, no. 10237, pp. 1595-1598, 2020, 
doi: 10.1016/S0140-6736(20)31034-5.

[4] P. L. Reiter, M. L. Pennell, and M. L. Katz, "Acceptability of a COVID-19 vaccine among adults in the United States: How many people would get vaccinated?," Vaccine, vol. 38, no. 42, pp. 6500-6507, 2020, doi: 10.1016/j.vaccine.2020.08.043.

[5] N. Ruan, T. Nguyen, and K. Khor, "China's Seasonal Influenza Vaccination Policy in a Post-Health Care Reform Era," Asia Pacific Policy Stud., vol. 2, no. 2, pp. 214-226, 2015, doi: 10.1002/app5.86.

[6] J. Kaldy, "Policy Remedies for Social Media Headaches," Caring Ages, vol. 16, no. 6, p. 11, 2015, doi: 10.1016/j.carage.2015.05.016.

[7] C. K. Jha and S. Sarangi, "Does social media reduce corruption?," Inf. Econ. Policy, vol. 39, pp. 60-71, 2017, doi: 10.1016/j.infoecopol.2017.04.001.

[8] M. C. C. Ortuoste, "Social Media, Public Discourse, and Governance," Asian Polit. Policy, vol. 7, no. 3, pp. 497-502, 2015, doi: 10.1111/app.12195.

[9] M.-P. S. Chan, K. Winneg, L. Hawkins, M. Farhadloo, K. H. Jamieson, and D. Albarracín, "Legacy and social media respectively influence risk perceptions and protective behaviors during emerging health threats: A multi-wave analysis of communications on Zika virus cases," Soc. Sci. Med., vol. 212, pp. 50-59, 2018, doi: 10.1016/j.socscimed.2018.07.007.

[10] R. Subramanian and A. Weare, "\#Notokay: Challenging Sexual Violence Through Digital Health Activism," Crit. Public Health, vol. 00, no. 00, pp. 1-10, 2020, doi: 10.1080/09581596.2020.1776218.

[11] A. Rochefort, "Regulating Social Media Platforms: A Comparative Policy Analysis," Commun. Law Policy, vol. 25, no. 2, pp. 225-260, 2020, doi: 10.1080/10811680.2020.1735194.

[12] Z. Lin, "Traditional Media, Social Media, and Alternative Media in Hong Kong's Umbrella Movement," Asian Polit. Policy, vol. 8, no. 2, pp. 365-372, 2016, doi: 10.1111/app.12258.

[13] K. J. Smith and L. Colvin, " Crafting a Social-Media Policy You Can 'Like'," Employ. Relat. Today, vol. 43, no. 2, pp. 93-99, 2016, doi: 10.1002/ert.21559.

[14] A. Macková, "Interpreting hashtag politics: policy ideas in an era of social media, by Stephen Jeffares," Crit. Policy Stud., vol. 10, no. 1, pp. 129-130, 2016, doi: 10.1080/19460171.2016.1154699.

[15] D. A. Gentile, "The Evolution of Scientific Skepticism in the Media Violence 'Debate," Anal. Soc. Issues Public Policy, vol. 16, no. 1, pp. 429-434, 2016, doi: 10.1111/asap.12110.

[16] V. Sunio, P. Peckson, and J. C. Ugay, "How urban social movements are leveraging social media to promote dignified mobility as a basic human right," Case Stud. Transp. Policy, 2020, doi: 10.1016/j.cstp.2020.07.006.

[17] L. Warwick-Giles, A. Coleman, and K. Checkland, "Co-owner, service provider, critical friend? The role of public health in clinical commissioning groups," J. Public Heal. (United Kingdom), vol. 38, no. 4, pp. 765-770, 2016, doi: 10.1093/Pubmed/fdv137.

[18] D. Banerjee, "The COVID-19 outbreak: Crucial role the psychiatrists can play," Asian J. Psychiatr., vol. 50, p. 102014, 2020, doi: 10.1016/j.ajp.2020.102014.

[19] C. S. Carpenter and E. C. Lawler, "Direct and spillover effects of middle school vaccination requirements," Am. Econ. J. Econ. Policy, vol. 11, no. 1, pp. 95-125, 2019, doi: $10.1257 /$ pol.20170067.

[20] A. Raoofi, A. Takian, A. A. Sari, A. Olyaeemanesh, H. Haghighi, and M. Aarabi, 
"COVID-19 pandemic and comparative health policy learning in Iran," Arch. Iran. Med., vol. 23, no. 4, pp. 220-234, 2020, doi: 10.34172/aim.2020.02.

[21] W. Liu, X. G. Yue, and P. B. Tchounwou, "Response to the covid-19 epidemic: The Chinese experience and implications for other countries," Int. J. Environ. Res. Public Health, vol. 17, no. 7, pp. 1-6, 2020, doi: 10.3390/IJERPH17072304.

[22] A. Dighe et al., "Response to COVID-19 in South Korea and implications for lifting stringent interventions," BMC Med., vol. 18, no. 1, 2020, doi: 10.1186/s12916-02001791-8.

[23] C. Sohrabi et al., "World Health Organization declares global emergency: A review of the 2019 novel coronavirus (COVID-19)," Int. J. Surg., vol. 76, no. February, pp. 7176, 2020, doi: 10.1016/j.jjsu.2020.02.034.

[24] B. Gates, "Responding to Covid-19 - A Once-in-a-Century Pandemic?," N. Engl. J. Med., vol. 382, no. 18, pp. 1677-1679, 2020, doi: 10.1056/nejmp2003762.

[25] A. Charalambous, "Social media and health policy," Asia-Pacific J. Oncol. Nurs., vol. 6, no. 1, pp. 24-27, 2019, doi: 10.4103/apjon.apjon-60-18.

[26] N. Miladi, "Social Media and Social Change," Dig. Middle East Stud., vol. 25, no. 1, pp. 36-51, 2016, doi: 10.1111/dome.12082.

[27] M. Fischer, "\#Free_CeCe: the material convergence of social media activism," Fem. Media Stud., vol. 16, no. 5, pp. 755-771, 2016, doi: 10.1080/14680777.2016.1140668.

[28] V. Sacco and D. Bossio, "Do not Tweet This!: How journalists and media organizations negotiate tensions emerging from the implementation of social media policy in newsrooms," Digit. Journal., vol. 5, no. 2, pp. 177-193, 2017, doi: 10.1080/21670811.2016.1155967.

[29] J. Adam, "Social media visibility: challenges to activism," Media, Cult. Soc., vol. 40, no. 1, pp. 41-58, 2018, doi: 10.1177/0163443717704997.

[30] K. Park and H. Rim, "'Click First!': The Effects of Instant Activism Via a Hoax on Social Media," Soc. Media Soc., vol. 6, no. 2, 2020, doi: 10.1177/2056305120904706. 